Saudi Journal of Oral and Dental Research

Abbreviated Key Title: Saudi J Oral Dent Res

ISSN 2518-1300 (Print) |ISSN 2518-1297 (Online)

Scholars Middle East Publishers, Dubai, United Arab Emirates

Journal homepage: https://saudijournals.com

\title{
Complications in Third Molar Extraction Outcome: A Systematic Review
}

Dr. Mohammed S AlSahhar", Dr. Amjad Obaid Aljohani, Dr. Saif Ahmed Alshaikhi, Dr. Amro Mohammed Abdulaziz, Dr. Anwar Minwer Alanazi, Dr. Sarah Ahmed Almohaimel, Dr. Maha Thaar Almutairi, Dr. Almuhanna Mohammed Ali, Dr. Shaima Mohammed Alasimi, Dr. Khadega Jaafar Alwi Alshateri, Dr. Fatima Sultana

Department of Dentistry, Kingdom of Saudi Arabia

DOI: $\underline{10.36348 / \text { sjodr.2020.v05i12.006 }}$

| Received: 03.12.2020 | Accepted: 15.12.2020 | Published: 18.12.2020

*Corresponding author: Dr. Mohammed S AlSahhar

\section{Abstract}

The third molars are the toughest, far-most and wide when compared to the other teeth and helps in grinding of food inside the oral cavity of the individual he most commonly impacted teeth in the human dentition is the third molars. Due to the impaction of the third molars, the oral and maxillofacial surgeons often extract the third molars by a surgical procedure. A planned surgical procedure is to be followed by the surgeons to minimize any complications related to the third molar extraction. The primary goal of this research was to review the literature related to complications after the third molar surgery. Data was extracted from the online databases like Medline and Pub Med Central, and tabulated using the pre-designed data extraction forms. Commonly the extractions are done by the general dentists using the forceps and elevator. In case of the tooth that is near a major nerve, with large or curved roots, in fusion with the jawbone or if it's nearby a crown or fillings the Dento alveolar surgery is recommended. These complications can affect the quality of life of the patient. In present time the knowledge and awareness about oral health and its impact on the quality of life is understood and maintained. The patient should be made aware about all the possible complications before the surgery.

Keywords: Third Molar Surgery, Dento Alveolar Surgery, Wisdom Tooth Surgery, Complications, impacted teeth.

Copyright () 2020 The Author(s): This is an open-access article distributed under the terms of the Creative Commons Attribution 4.0 International License (CC BY-NC 4.0) which permits unrestricted use, distribution, and reproduction in any medium for non-commercial use provided the original author and source are credited.

\section{INTRODUCTION}

Due to varied reasons, the protruding of the teeth through the gingiva is blocked and the tooth is impacted inside the gingiva, this is called impaction of Teeth. The teeth can be partially impacted or completely impacted [1]. The partially impacted has started to erupt through the gingiva while the impacted teeth failed to erupt and is inside the gingiva [2]. Most of the time, the teeth that are impacted remain under the gingiva with no problems to the individual, however it can be only seen via a X-ray of the oral cavity [3].The sign and symptoms of an impacted tooth are: pain in the oral cavity while opening the mouth, biting and chewing; the mouth opens with lots of difficulty; bad breath; bad taste in mouth; inflammed red bleeding gingiva [4]. The cause of tooth impaction may be excessive soft tissue, dense overlying bone, abnormal eruption path, length and space of the dental arch. The tooth becomes impacted when the space inside the dental arch is reduced due to orthodontic treatment [5]. The most commonly impacted teeth in Human is the mandibular and maxillary Third morals followed by maxillary canines and mandibular canines [6,7]. The Global dental data suggests that at least $73 \%$ of the population has at least one impacted tooth in the oral cavity. It was reported that the prevalence and incidence of the impacted tooth is increasing due to enhanced use of soft food in diets and comparatively less use of masticatory apparatus. The age, gender and race of the individual influence the occurrence of impacted tooth [8].

\section{AIM AND OBJECTIVES}

The primary goal of this research was to review the literature related to complications after the third molar surgery. This can be attained by:

- Carrying out an online search of databases for the literature related to complications after the third molar surgery.

- Systematically reviewing the literature available on Pubmed Central, Medline, Scopus, Embase, Google Scholar, etc.

- Identifying the varied reasons for the cause of complications after the surgery.

- Identifying the risk factors for complications of the third molar surgery.

- Determining the possible precautionary steps to be taken during the third molar surgery. 


\section{METHODOLOGY}

To perform the systematic search using the Medline and Pub Med Central in the English language with the aim to review the literature related to the complications after the third molar extraction. Data was extracted from the online databases like Medline and Pub Med Central, and tabulated using the pre-designed data extraction forms.

\section{DATA EXTRACTION}

The pre-designed data extraction form included the information about the study citation and characteristics (name of the Author/s, year of publication, country of study, complications in the patient after the third molar extraction). The complication reported can be intra-operative / immediate / intermediate / delayed depending upon the onset of occurrence after the Dento alveolar surgery.

\section{DATA MANAGEMENT}

Extracted data from Medline and Pub Med Central is to be entered in the pre-designed data extraction form created by Principal Investigator. The outcome will be observed and the results will be recorded. Each article selected for the study will be closely reviewed and the data entered in the predesigned tables are evaluated and handled by the principal investigator.

\section{SEARCH TERMS USED}

Third Molars OR Wisdom Teeth OR Grinders OR Posterior Molars OR Last Molars AND Dento Alveolar Surgery OR Oral-maxillofacial Surgery OR Oral Surgery OR Oral and Maxillofacial Surgery OR Dento Alveolar Osteotomy AND Maxillary OR Maxilla AND Mandibular OR Mandible AND Complications OR Complaints OR Ailments.

\section{FILTERS USED}

Human studies, studies in English language, adults of 18 years and old

\section{TIME LINE OF STUDY}

A total of 6 months time it took to collect the data, analyze it, write the manuscript and proposal, and review the manuscript and proposal.

\section{DATA ANALYSIS}

The literature review showed a total of 778 articles related to the MeSH terms used. By applying the filters and limiting the articles with human studies, adult studies and English language studies, about 196 were sorted to study. The abstracts and titles were studied and by applying the inclusion and exclusion criteria, about 37 articles were selected and from this upon further assessment 24 articles were removed and only 13 articles were included in the study of postoperative complications of the Third Molars.

\begin{tabular}{|c|c|c|c|c|}
\hline $\begin{array}{l}\text { AUTHORS } \\
\text { NAME }\end{array}$ & $\begin{array}{l}\text { YEAR } \\
\text { OF } \\
\text { STUDY }\end{array}$ & RESEARCH TOPIC & $\begin{array}{l}\text { COMPLICATIONS } \\
\text { REPORTED }\end{array}$ & $\begin{array}{l}\text { DATA } \\
\text { SOURCE }\end{array}$ \\
\hline $\begin{array}{l}\text { Medeiros And } \\
\text { Bezerra }\end{array}$ & 1997 & $\begin{array}{l}\text { Treatment Of An Ankylosed Central } \\
\text { Incisor By Single-Tooth Dento-Osseous } \\
\text { Osteotomy }\end{array}$ & $\begin{array}{l}\text { Surgical } \\
\text { Repositioning }\end{array}$ & $\begin{array}{l}\text { Am J Orthod } \\
\text { Dentofac } \\
\text { Orthop }\end{array}$ \\
\hline Kral And Subrt & 1966 & $\begin{array}{l}\text { Repositioning Of a Single Tooth By } \\
\text { Means Of Corticotomy And Fracturing } \\
\text { Of Its Alveolar Process] }\end{array}$ & $\begin{array}{l}\text { Tooth Vitality After } \\
\text { The Treatment }\end{array}$ & $\begin{array}{l}\text { Osterr Z } \\
\text { Stomatol }\end{array}$ \\
\hline Kole & 1959 & $\begin{array}{l}\text { Surgical Operations On The Alveolar } \\
\text { Ridge To Correct Occlusal } \\
\text { Abnormalities. }\end{array}$ & $\begin{array}{l}\text { Buccal And Lingual } \\
\text { Alveolar Bone }\end{array}$ & $\begin{array}{l}\text { Oral Surg Oral } \\
\text { Med Oral } \\
\text { Pathol. }\end{array}$ \\
\hline Düker & 1975 & $\begin{array}{l}\text { Experimental Animal Research Into } \\
\text { Segmental Alveolar Movement After } \\
\text { Corticotomy. }\end{array}$ & $\begin{array}{l}\text { Rapid Tooth } \\
\text { Movement With } \\
\text { Corticotomy }\end{array}$ & $\begin{array}{l}\text { J Maxillofac } \\
\text { Surg. }\end{array}$ \\
\hline Suya & 1991 & $\begin{array}{l}\text { Suya H. Corticotomy In Orthodontics. } \\
\text { In: Hosl E, Baldauf A, } \\
\text { Editors. Mechanical And Biological } \\
\text { Basis In Orthodontic Therapy. }\end{array}$ & $\begin{array}{l}\text { Corticotomy-Assisted } \\
\text { Orthodontic } \\
\text { Treatment }\end{array}$ & $\begin{array}{l}\text { Heidelberg, } \\
\text { Germany: } \\
\text { Huthig Buch } \\
\text { Verlag }\end{array}$ \\
\hline Yaffe & 1994 & $\begin{array}{l}\text { Regional Accelerated Phenomenon In } \\
\text { The Mandible Following Mucoperiosteal } \\
\text { Flap Surgery. }\end{array}$ & $\begin{array}{l}\text { Osteotomy-Assisted } \\
\text { Tooth Movement }\end{array}$ & J Periodontol. \\
\hline Wilcko & 2000 & $\begin{array}{l}\text { Rapid Orthodontics With Alveolar } \\
\text { Reshaping: Two Case Reports Of } \\
\text { Decrowding }\end{array}$ & $\begin{array}{l}\text { Reversible } \\
\text { Osteopenia }\end{array}$ & $\begin{array}{l}\text { Int J } \\
\text { Periodontics } \\
\text { Restorative } \\
\text { Dent. }\end{array}$ \\
\hline Lee $\mathrm{W}$ & 2008 & $\begin{array}{l}\text { Corticotomy-/Osteotomy-Assisted Tooth } \\
\text { Movement Microcts Differ. }\end{array}$ & $\begin{array}{l}\text { Transient Bone } \\
\text { Resorption }\end{array}$ & J Dent Res. \\
\hline
\end{tabular}




\begin{tabular}{|l|l|l|l|l|}
\hline \hline Wang & 2009 & $\begin{array}{l}\text { Tisssue Responses In Corticotomy- And } \\
\text { Osteotomy-Assisted Tooth Movements } \\
\text { In Rats: Histology And Immunostaining. }\end{array}$ & $\begin{array}{l}\text { Distraction } \\
\text { Osteogenesis }\end{array}$ & $\begin{array}{l}\text { Am J Orthod } \\
\text { Dentofacial } \\
\text { Orthop. }\end{array}$ \\
\hline Leung Yy & 2012 & $\begin{array}{l}\text { Treatment Modalities Of Neurosensory } \\
\text { Deficit After Lower Third Molar } \\
\text { Surgery: A Systematic Review }\end{array}$ & $\begin{array}{l}\text { J Oral } \\
\text { Maxillofac } \\
\text { Surg. 2 }\end{array}$ \\
\hline Thirumurgan K & 2013 & $\begin{array}{l}\text { Maxillary Tuberosity Fracture And } \\
\text { Subconjunctival Hemorrhage Following } \\
\text { Extraction Of Maxillary Third Molar. }\end{array}$ & $\begin{array}{l}\text { Fracture of The } \\
\text { Maxillae }\end{array}$ & $\begin{array}{l}\text { J Nat Sci Biol } \\
\text { Med. }\end{array}$ \\
\hline Marghalani A & 2014 & $\begin{array}{l}\text { Antibiotic Prophylaxis Reduces } \\
\text { Infectious Complications But Increases } \\
\text { Adverse Effects After Third-Molar } \\
\text { Extraction In Healthy Patients. }\end{array}$ & $\begin{array}{l}\text { Post-Operative } \\
\text { Infections }\end{array}$ & Jada \\
\hline $\begin{array}{l}\text { Elitsa G. } \\
\text { Deliverska }\end{array}$ & 2016 & $\begin{array}{l}\text { Complications After Extraction Of } \\
\text { Impacted Third Molars- Literature } \\
\text { Review }\end{array}$ & $\begin{array}{l}\text { Pain. Dry Socket, } \\
\text { Swelling }\end{array}$ & Imab \\
\hline
\end{tabular}

\section{Third molars}

The third molars are often called as the Wisdom teeth, as they erupt in a wise age between 17 to 21 years of age. The third molars are the toughest, farmost and wide when compared to the other teeth and helps in grinding of food inside the oral cavity of the individual. In the human dentition, the third molars are the most posterior teeth of all. If no or less space is available for the eruption of the third molars, they get impacted. The most commonly impacted teeth in the human dentition are the third molars. Due to the impaction of the third molars, the oral and maxillofacial surgeons often extract the third molars by a surgical procedure. A planned surgical procedure is to be followed by the surgeons to minimize any complications related to the third molar extraction.

\section{Third molar extraction (dento alveolar surgery)}

Commonly the extractions are done by the general dentists using the forceps and elevator. In case of the tooth that is near a major nerve, with large or curved roots, in fusion with the jawbone or if it's nearby a crown or fillings the Dento alveolar surgery is recommended. The Dento alveolar Surgery is performed by the Oral and Maxillofacial surgeon. The Dento alveolar surgery can be performed by using local anaesthesia on the dental chair or by giving General anaesthesia in the operation theatre. The surgical extraction may involve the incision in the gingiva or the removal of the surrounding bone to have an access to the teeth and then removing the teeth easily by extraction technique. Sutures are done on the gum line once the teeth are removed. The pain relief medicine and soft diet for the patient is recommended by the surgeon. The time of healing varies from one patient to other depending on many factors. However the healing time for a Dento alveolar surgery is more when compared with simple extractions.

\section{Complications after the third molar extraction (dento alveolar surgery}

The complication related to the third molar extraction can vary in severity depending on the age of the patient. The pain and the healing time can be more in elder patients when compared with the younger patients. The complications may arise due to osteoporosis seen in the patient; dental alkylosis; use of coagulation drugs.

\begin{tabular}{|l|l|}
\hline Complications during the surgery & Complications after the surgery \\
\hline Impacted/Adjacent Tooth & Pain \\
\hline Displacement of the Third Molar & Swelling and Surgical edema: \\
\hline Soft Tissue & Trismus: \\
\hline Nerve Injuries: & Infection: \\
\hline Bone Complications & Bone/Soft Tissue Haemorrhage \\
\hline Maxillary Sinus: & Delayed Healing \\
\hline Swallowing and Aspiration: & Wound Dehiscense \\
\hline
\end{tabular}

\section{DURING THE SURGERY}

The complications during the third molar extraction surgery may be due to

1) Impacted/Adjacent Tooth: The irregular position of the third molar may cause development of caries in the adjacent second molars that can cause complication during the surgery. The fracture of the adjacent second molar crown is expected and needed restoration. The fixation of the adjacent tooth can be done using arch bars, dental wires and composite splints.

2) Displacement of the Third Molar: During the surgical extraction of the third molar accidental displacement of the tooth can occur into the maxillary sinus space, lingual space, infra-temporal space, submandibular space. The clinical symptoms of the displaced third molar during the surgery may be, 
swelling, inflammation and oedema in the cheek and neck.

3) Soft Tissue: Surgical emphysema, haemorrhage, Bichat fat pad, haematoma formation can occur to the adjacent soft tissues during the surgical extraction. The age of the patient, inclination of the tooth and also the position of the tooth to be extracted place a role in occurrence of these complications.

4) Nerve Injuries: The nerve injuries are common in case of the mandibular Third molars. Due to the surgical procedures and anaesthesia the nerve injury can occur. The nerve injuries may lead to Neuropraxia, Neurotmesis/Axonotmesis. The neuro sensory dysfunction may cause numbness, paraesthesia, dysesthesia and hypoesthesia. The facial nerve paralysis may also occur after the maxillary third molar surgery.

5) Bone Complications: The Maxillary or mandibular bone fracture may occur during the third molar extraction surgery. Factors that effects the maxillary or mandibular bone fracture may be shape, size and number of dental roots, dental alkylosis, patient age, tooth position, presence of odontogenic lesions, atrophic or sclerotic mandible. The study reports low prevalence of tooth fracture in case of young patients when compared with old patients. Clinical signs may be hearing of a cracking sound, observable hollow socket. 6) Maxillary Sinus: If an oro-antral communication present, the extraction of the impacted maxillary third molar may develop the maxillary sinusitis. The higher degree of impaction and older age influences the formation of the maxillary sinus.

7) Surgical Equipment: Heat and torsion may result in metal fracturing with the surgical equipment during the surgery. During the surgery, improper use of the force may lead to fracture of the bone. If fracture is observed than the fragments need to be immediately removed.

8) Swallowing and Aspiration: The swallowing or aspiration may occur during the surgery accidentally. The main reason may be inexperienced dental surgeon behind this complication. It's a rare complication and the level of incidence is only $0.004 \%$.

\section{After the surgery}

1) Pain: After 6 to 12 hours of surgery, when the effects of anaesthesia are gone, the pain is at peak. Long duration of surgery leads to high tissue injury. Corticosteroids, analgesics can be given to reduce pain after the surgery. The incidence of pain is less in case of secondary wound healing when compared with the primary wound healing.

2) Swelling and Surgical edema: The maximum swelling and edema is seen in 2 to 3 days while it would be resolved in 7 days post-surgery. The facial swelling is determined by body surface, sex and weight. The use of corticosteroids and ice can reduce the swelling in the facial tissues.

3) Trismus: The difficulty in opening the mouth is called as trismus. It can occur due to the inflammation of the masticatory muscle and surgical trauma after the surgical extraction of the third molars. Also during the surgery, if the mouth is kept open for a long time trismus may happen. The patients are advised to do facial exercise and muscle relaxants (chlorzoxazone tablets) post operation.

4) Infection: The post-operative infections following the third molar extractions may cause inflammation may lead to development of abscess. The infections after the third molar extractions can cause alveolar osteitis, alveolitis, dry sockets and osteomyelitis. The pre and post-operative use of chlorhexidine can prevent infections. The damaged and injured tissues leads to the development of bacteria that multiplies and cause infection and form dry pockets.

5) Bone/Soft Tissue Haemorrhage: One or more cause can lead to the bleeding post third molar extraction surgery. Hermetically healing the suture can reduce the bleeding after the surgery.

6) Delayed Healing and Wound Dehiscense: The flap is sutured to its original position after the extraction surgery of the third molar, this is the primary healing. The secondary healing may cause continuous pain and discomfort to the patient but it also few advantages like reduced trismus and swelling after the surgery. Wound Dehiscence also may occur if proper care is not taken by surgeon.

\section{CONCLUSION}

Mostly the extraction of the Third Molar by a surgical procedure may lead to the post-operative complications. These complications can affect the quality of life of the patient. In present time the knowledge and awareness about oral health and its impact on the quality of life is understood and maintained. The patient should be made aware about all the possible complications before the surgery. The surgeons should be made aware about treating all these complications.

\section{ETHICAL CONSIDERATIONS Compliance with ethical standards}

\section{Ethical approval}

This proposal does not contain any studies with human participants performed by any of the authors.

\section{Conflict of interest}

The authors do not have any commercial associations that might pose or create a conflict of interest with information presented in this communication. No intramural or extramural funding supported any aspect of this work

\section{REFERENCES}

1. Miloro, M., Ghali, G. E., Larsen, P. E., \& Waite, P. (2004). Peterson's Principles of Oral and Maxillofacial Surgery. vol. 1. Hamilton: BC Decker Inc.

2. Khan, A. (2010). Impacted mandibular third molars: pattern of presentation and postoperative 
complications. Pakistan Oral \& Dental Journal, 30(2).

3. Darawade, D. A., Kumar, S., Mehta, R., Sharma, A. R., \& Reddy, G. S. (2014). In search of a better option: dexamethasone versus methylprednisolone in third molar impaction surgery. Journal of international oral health: JIOH, 6(6), 14.

4. Hooley, J. R., \& Francis, F. H. (1969). Betamethasone in traumatic oral surgery. Journal of oral surgery (American Dental Association: 1965), 27(6), 398.

5. Suarez-Cunqueiro, M. M., Gutwald, R., Reichman, J., Otero-Cepeda, X. L., \& Schmelzeisen, R. (2003). Marginal flap versus paramarginal flap in impacted third molar surgery: a prospective study. Oral Surgery, Oral Medicine, Oral Pathology, Oral Radiology, and Endodontology, 95(4), 403-408.

6. Holland, C. S., \& Hindle, M. O. (1984). The influence of closure or dressing of third molar sockets on post-operative swelling and pain. British Journal of Oral and Maxillofacial Surgery, 22(1), 65-71.

7. Vezeau, P. J. (2000). Dental extraction wound management: medicating postextraction sockets. Journal of Oral and Maxillofacial Surgery, 58(5), 531-537.

8. Chrcanovic, B. R., \& Freire- Maia, B. (2011). Considerations of maxillary tuberosity fractures during extraction of upper molars: a literature review. Dental Traumatology, 27(5), 393-398.

9. Medeiros, P. J., \& Bezerra, A. R. (1997). Treatment of an ankylosed central incisor by single-tooth dento-osseous osteotomy. American journal of orthodontics and dentofacial orthopedics, 112(5), 496-501.

10. Král, A., \& Subrt, I. (1966). Repositioning of a single tooth by means of corticotomy and fracturing of its alveolar process. Osterreichische Zeitschrift fur Stomatologie, 63(6), 235.

11. Köle, H. (1959). Surgical operations on the alveolar ridge to correct occlusal abnormalities. Oral Surgery, Oral Medicine, Oral Pathology, 12(5), 515-529.

12. Düker, J. (1976). Histological studies on rapid dental group movements following corticotomy in the animal experiment. Fortschritte der Kiefer-und Gesichts-Chirurgie, 21, 72.

13. Suya, H. (1991). Corticotomy in orthodontics. Mechanical and biological basics in orthodontic therapy.

14. Yaffe, A., Fine, N., \& Binderman, I. (1994). Regional accelerated phenomenon in the mandible following mucoperiosteal flap surgery. Journal of periodontology, 65(1), 79-83.

15. Wilcko, W. M., Wilcko, M. T., Bouquot, J. E., \& Ferguson, D. J. (2000). Accelerated orthodontics with alveolar reshaping. J Ortho Practice, 10(1), 63-70.

16. Lee, J. K., Chung, K. R., \& Baek, S. H. (2007). Treatment outcomes of orthodontic treatment, corticotomy-assisted orthodontic treatment, and anterior segmental osteotomy for bimaxillary dentoalveolar protrusion. Plastic and reconstructive surgery, 120(4), 1027-1036.

17. Wang, L., Lee, W., Lei, D. L., Liu, Y. P., Yamashita, D. D., \& Yen, S. L. K. (2009). Tisssue responses in corticotomy-and osteotomy-assisted tooth movements in rats: histology and immunostaining. American Journal of Orthodontics and Dentofacial Orthopedics, 136(6), 770-e1.

18. Leung, Y. Y., Fung, P. P. L., \& Cheung, L. K. (2012). Treatment modalities of neurosensory deficit after lower third molar surgery: a systematic review. Journal of Oral and Maxillofacial Surgery, 70(4), 768-778.

19. Thirumurugan, K., Munzanoor, R. R. B., Prasad, G. A., \& Sankar, K. (2013). Maxillary tuberosity fracture and subconjunctival hemorrhage following extraction of maxillary third molar. Journal of Natural Science, Biology, and Medicine, 4(1), 242.

20. Marghalani, A. (2014). Antibiotic prophylaxis reduces infectious complications but increases adverse effects after third-molar extraction in healthy patients. The Journal of the American Dental Association, 145(5), 476-478.

21. Deliverska, E. G., \& Petkova, M. (2016). Complications after extraction of impacted third molars-literature review. Journal of IMAB-Annual Proceeding Scientific Papers, 22(3), 1202-1211. 